\title{
Alternative Media for the Mycological Diagnosis of Fungal Infections in Rural Areas
}

Jan Susilo

\begin{abstract}
Abstrak
Karena penyakit infeksi oleh kuman, virus dan parasit masih banyak ditemukan di Indonesia, maka sebagian besar perhatian dokter dicurahkan untuk kemungkinan infeksi oleh penyebab tersebut di atas. Penyakit jamur jarang dilaporkan di Indonesia. Hal tersebut dapat disebabkan oleh kurangnya perhatian atau kesulitan dalam pembuktian secara laboratoris. Meskipun banyak terdapat laboratorium mikrobiologi, tidak banyak yang melakukan pemeriksaan terhadap jamur. Salah satu sebabnya ialah, agar Sabouraud dekstrosa, medium standar untuk isolasi jamur, mahal harganya dan masih diimpor dari luar negeri. Suatu medium alternatif yang menggunakan bahan yang mudah didapat dan murah, yaitu air kelapa (dari buah muda [Y] atau buah tua [R]), tepung kacang hijau (GB) atau monosodium glutamat (MSG) dan agar, telah dikemukakan. Penelitian ini dilakukan untuk menilai medium baru tersebut sebagai pengganti agar Sabouraud dekstrosa (S), untuk pertumbuhan 12 strain jamur. Tiap strain dibiakkan pada masing masing 4 tabung GBY, GBR, MGY, MSGR dan S. Percobaan ini diulang empat kali. Diusahakan untuk membiakkan 1 mm3 jamur pada tiap tabung. Tabung yang telah diinokulasi disimpan pada suhu kamar dan dinilai setelah satu minggu. Hasil penelitian ini menunjukkan bahwa tidak terdapat perbedaan antara agar air kelapa kacang hijau atau agar air kelapa monosodium glutamat dan agar Sabouraud dekstrosa untuk pembiakan beberapa spesies jamur yang sering menimbulkan kelainan pada manusia. Hasil tersebut mendukung pendapat bahwa kedua medium yang diajukan dapat digunakan sebagai pengganti agar Saboraud dekstrosa.
\end{abstract}

\begin{abstract}
As bacterial, viral and parasitic infections are still in Indonesia, most attention of the physicians are drawned to these possibilities. Mycotic infections in Indonesia have been reported rarely. This could be due to inadequate attention of the physicians or difficulty in laboratory confirmation. Although there are many microbiology laboratories, not many mycological examinations were done. One of the reasons is that Sabouraud dextrose agar, the standard medium for the isolation of fungi, is expensive and still imported. An alternative medium using locally available and cheap ingredients, namely coconut water (from young [Y] or ripe [R] fruits), green bean (GB) flour or monosodium glutamate (MSG) and agar, was proposed. This research was aimed to evaluate the proposed new medium as a possible substitute for Sabouraud dextrose agar (S) for the growth of 12 strains of fungi. Each of the fungal isolates were cultured in four tubes of GBY, GBR, MSGY, MSGR and S. These tests were repeated four times. Care was taken to transfer about $1 \mathrm{cmm}$ of inoculum in each tube. All cultures were put in room temperature and evaluated one week after inoculation. Results showed that there is no significant difference between green bean coconut water agar or monosodium glutamate coconut water agar and Sabouraud dextrose agar for the growth of several species of fungi which are common etiologic agents of mycoses in man, thus confirming that the two proposed media could be used as substitute for Sabouraud dextrose agar.
\end{abstract}

Keywords : Mycosis,. medium, Sabouraud agar, coconut water, green-bean flour, monosodium glutamate

\section{INTRODUCTION}

Mycoses in Indonesia, as in many other tropical countries, are not getting their fair share of attention. Although temperature, humidity and environment are optimal for fungal growth almost anywhere, not many mycotic infection were reported or known.

Fungal infections, notably systemic mycosis, are seldom recognized or confirmed by laboratory examinations in rural as well as in urban areas. Diag- nosis of acute superficial fungal infections is usually based on clinical signs and symptoms. This may not be easy in chronic cases, particularly if there is secondary bacterial infection. In systemic mycosis, signs and symptoms are not characteristic and could not be differentiated from other systemic infections. Mycological examinations are necessary to confirm the diagnosis.

As bacterial, viral and parasitic infections are still prominent in Indonesia, most attention are drawned to

Mycology Section, Department of Parasitology, Faculty of Medicine, University of Indonesia, Jakarta, Indonesia 
these possibilities. Although there are many clinical laboratories in the cities and health care centers found in villages, mycological examinations are seldom done. This is due to the lack of expertise in the part of the laboratory technicians and the unavailability of the medium to isolate the causative fungus. Most bacterial and mycological media are still imported from other countries. The increasing prices of these media, the problem of continuous supply of the medium and the easily deteriorated dry medium due to high humidity lead to the high cost of mycological examinations. Although many media for the isolation of bacteria are suitable for the growth of fungi, bacteriological examinations are evaluated in three or four days. Most of the fungal pathogens take much longer time to grow. This is one of the reasons why most of the pathogenic fungi are not isolated. This paper presents an alternative medium for the isolation of fungi from clinical specimens, using locally available and cheap agricultural products as a substitute for the standard Sabouraud dextrose agar. As these media are intended to be used in rural areas, the methods proposed to make the media do not employ sophisticated apparatus.

\section{MATERIALS AND METHODS}

Efforts were made to replace the ingredients of Sabouraud dextrose agar with locally available and cheap agricultural product. As the base for the medium, agar, which is usually used to make pudding, was used to replace the more expensive and purified bacteriological agar. Dextrose and distilled water were replaced with coconut-water, which contains 4-5\% carbohydrate and minerals. Pepton as the source of protein was substituted with green bean flour or monosodium glutamate which are commercially available.

Agar powder is sold in a $7 \mathrm{gr}$ package which is recommended to make 1 liter of pudding. Two of these packages were dissolved in 1.5 l of coconut water from young or ripe coconut fruit. Two table spoonful (about $10 \mathrm{gr}$ ) of green bean flour or monosodium glutamate was added. The mixture was boiled and dispensed in test tubes, each containing $5 \mathrm{ml}$ of the liquid agar mixture. Then the tubes were stoppered with cotton plug, put into pressure cooker and boiled for 15 minutes. These tubes could also be sterilized by boiling or steaming for 20 minutes. After sterilization the tubes were put in a slant position to cool.

Five dermatophytes and one Candida albicans strains isolated from skin scrapings, 4 strains of fungi causing deep seated fungal infection and two strains of contaminants were used to test the green-bean coconut-water agar (GBY = utilizing coconut water from young coconut fruit, GBR = utilizing coconut water from ripe coconut fruit) and monosodium glutamate agar (MSGY = utilizing coconut water from young coconut fruit, MSGR = utilizing coconut water from ripe coconut fruit). Sabouraud dextrose agar (S) was used as a comparison medium. Each of the fungal isolates was cultured in four tubes of GBY, GBR, MSGY, MSGR and S. These tests were repeated four times. Care was taken to transfer about $1 \mathrm{cmm}$ of inoculum in each tube. All cultures were put in room temperature and evaluated one week after inoculation.

\section{RESULTS}

All five dermatophytes and Candida albicans isolates grew in every tube of GBY, GBR, MSGY, MSGR and $S$ and the fungi could be identified after one week (Table 1).

Table 1 . The growth of 6 isolates of fungi on 5 different media

\begin{tabular}{|c|c|c|c|c|c|c|}
\hline Medium & $\mathrm{Tm}$ & Tr & $\mathrm{Mg}$ & Mc & Ef & $\mathrm{Ca}$ \\
\hline GBY & * $16 / 16$ & $16 / 16$ & $16 / 16$ & $16 / 16$ & $16 / 16$ & $16 / 16$ \\
\hline GBR & $16 / 16$ & $16 / 16$ & $16 / 16$ & $16 / 16$ & $16 / 16$ & $16 / 16$ \\
\hline MSGY & $16 / 16$ & $16 / 16$ & $16 / 16$ & $16 / 16$ & $16 / 16$ & $16 / 16$ \\
\hline MSGR & $16 / 16$ & $16 / 16$ & $16 / 16$ & $16 / 16$ & $16 / 16$ & $16 / 16$ \\
\hline s & $16 / 16$ & $16 / 16$ & $16 / 16$ & $16 / 16$ & $16 / 16$ & $16 / 16$ \\
\hline BY & \multicolumn{6}{|c|}{$\begin{aligned}= & \text { Green bean agar utilizing coconut water from } \\
& \text { young fruit }\end{aligned}$} \\
\hline GBR & \multicolumn{6}{|c|}{$\begin{array}{l}=\text { Green bean agar utilizing coconut water from } \\
\text { ripe fruit }\end{array}$} \\
\hline MSGY & \multicolumn{6}{|c|}{$\begin{aligned}= & \text { Monosodium glutamate agar utilizing coconut } \\
& \text { water from young fruit }\end{aligned}$} \\
\hline MSGR & \multicolumn{6}{|c|}{$\begin{aligned}= & \text { Monosodium glutamate agar utilizing coconut } \\
& \text { water from ripe fruit }\end{aligned}$} \\
\hline 5 & \multicolumn{6}{|c|}{$=$ Sabouraud dextrose agar } \\
\hline $\mathrm{Tm}$ & \multicolumn{6}{|c|}{$=$ Trichophyton mentagrophytes } \\
\hline $\operatorname{Tr}$ & \multicolumn{6}{|c|}{$=$ Trichophyton rubrum } \\
\hline Mc & \multicolumn{6}{|c|}{$=$ Microsporum canis } \\
\hline $\mathrm{Mg}$ & \multicolumn{6}{|c|}{$=$ Microsporum gypseum } \\
\hline Ef & \multicolumn{6}{|c|}{$=$ Epidermophyton floccosum } \\
\hline $\mathrm{Ca}$ & \multicolumn{6}{|c|}{$=$ Candida albicans } \\
\hline 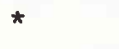 & \multicolumn{6}{|c|}{$=n 1 / n 2$} \\
\hline n1 & \multicolumn{6}{|c|}{$=$ Number of tubes with fungal growth } \\
\hline n2 & \multicolumn{6}{|c|}{$\begin{array}{l}=\text { Number of tubes inoculated (four groups of four } \\
\text { tubes) }\end{array}$} \\
\hline
\end{tabular}

Four strains of fungi causing systemic fungal infection, Histoplasma capsulatum, Cryptococcus neofor- 
mans, Aspergillus fumigatus and Sporothrix schenckii and two strains of contaminants, Hormodendrum sp and Cephalosporium $s p$, also grew in every tubes of the proposed media and Sabouraud dextrose agar (Table 2).

Table 2. The growth of 4 isolates of fungi causing systemic fungal infection and 2 isolates of contaminants on 5 different media

\begin{tabular}{|c|c|c|c|c|c|c|}
\hline Medium & Hc & $\mathrm{Cn}$ & Af & Ss & $\mathrm{Ce}$ & Ho \\
\hline GBY & * $16 / 16$ & $16 / 16$ & $16 / 16$ & $16 / 16$ & $16 / 16$ & $16 / 16$ \\
\hline GBR & $16 / 16$ & $16 / 16$ & $16 / 16$ & $16 / 16$ & $16 / 16$ & $16 / 16$ \\
\hline MSGY & $16 / 16$ & $16 / 16$ & $16 / 16$ & $16 / 16$ & $16 / 16$ & $16 / 16$ \\
\hline MSGR & $16 / 16$ & $16 / 16$ & $16 / 16$ & $16 / 16$ & $16 / 16$ & $16 / 16$ \\
\hline$S$ & $16 / 16$ & $16 / 16$ & $16 / 16$ & $16 / 16$ & $16 / 16$ & $16 / 16$ \\
\hline GBY & \multirow{2}{*}{\multicolumn{6}{|c|}{$\begin{array}{l}=\text { Green bean agar utilizing coconut water from } \\
\text { young fruit } \\
=\text { Green bean agar utilizing coconut water from ripe } \\
\text { fruit }\end{array}$}} \\
\hline GBR & & & & & & \\
\hline MSGY & \multicolumn{6}{|c|}{$\begin{aligned}= & \text { Monosodium glutamate agar utilizing coconut } \\
& \text { water from young fruit }\end{aligned}$} \\
\hline MSGR & \multicolumn{3}{|c|}{$\begin{aligned}= & \text { Monosodium glutamate } \\
& \text { water from ripe fruit }\end{aligned}$} & agar ut & ilizing & coconut \\
\hline$S$ & \multicolumn{6}{|c|}{$=$ Sabouraud dextrose agar } \\
\hline Hc & \multicolumn{6}{|c|}{$=$ Histoplasma capsulatum } \\
\hline $\mathrm{Cn}$ & \multicolumn{6}{|c|}{$=$ Cryptococcus neoformans } \\
\hline As & \multicolumn{6}{|c|}{$=$ Aspergillus fumigatus } \\
\hline Ss & \multicolumn{6}{|c|}{$=$ Sporothrix schenckii } \\
\hline $\mathrm{Ce}$ & \multicolumn{6}{|c|}{$=$ Cephalosporium sp. } \\
\hline Ho & \multicolumn{6}{|c|}{$=$ Hormodendrum sp. } \\
\hline & \multicolumn{6}{|c|}{$=\mathrm{n} 1 / \mathrm{n} 2$} \\
\hline 11 & \multicolumn{6}{|c|}{$=$ Number of tubes with fungal growth } \\
\hline 12 & \multicolumn{6}{|c|}{$\begin{array}{l}=\begin{array}{l}\text { Number of tubes inoculated (four groups of four } \\
\text { tubes) }\end{array}\end{array}$} \\
\hline
\end{tabular}

\section{DISCUSSION}

Results of the tests showed that the proposed media were able to grow fungi isolated from patients and other isolates, and were as good as Sabouraud dextrose agar. The fungi cultures could be identified after one week. More species and strains of other fungi should be tested. As the fungi tested were isolates from clinical specimens, except two strains which were contaminants, the proposed media should be able to isolate causative fungi directly from clinical materials. Isolation of fungi from clinical materials with the proposed media are being done. Although some fungi may seem to grow faster and better in Sabouraud dextrose agar or the proposed media, no attempt was made to compare these media quantitatively. The main objective of this research was to find a cheap and locally available ingredients to make mycological media to substitute the expensive and imported Sabouraud dextrose agar. As these media were made without employing sophisticated apparatus, these media could be made almost in any laboratory or health care centers.

The low prize and easily available ingredients to make these media could help medical doctors and their staff to make their own medium almost anywhere in Indonesia or in any other tropical countries. These media could also be used as transfer media and they could send the isolated fungi to reference mycology laboratory, should there be difficulty in identifying the isolated fungi.

\section{CONCLUSION}

Alternative media containing coconut water, greenbean flour or monosodium glutamate and agar can be used to grow fungi and are as good as Saboraud dextrose agar.

\section{REFERENCES}

1. Emmons CW, Binford UJ, Kwon Chung.C, editors. New York: Lea \& Febiger, 1978

2. Rippon JW. Medical Mycology. Philadelphia: Saunders, 1988.

3. Susilo J. An alternative medium for the isolation of fungi and some effort to improve the diagnosis and management of mycoses [disertation]. Jakarta: University of Indonesia, 1992. 